\title{
Analysis of Spectral Signatures of Silicone-Based Sealant Materials Used in Residential and Commercial Buildings
}

\author{
Aschalew Kassu' ${ }^{1}$, Carlton Farley III², Jonathan Mills², Anup Sharma² \\ ${ }^{1}$ Department of Mechanical, Civil Engineering and Construction Management, Normal, USA \\ ${ }^{2}$ Department of Physics, Chemistry, and Mathematics, Alabama A \& M University, Normal, USA \\ Email: aschalew.kassu@aamu.edu
}

How to cite this paper: Kassu, A., Farley III, C., Mills, J. and Sharma, A. (2018) Analysis of Spectral Signatures of Silicone-Based Sealant Materials Used in Residential and Commercial Buildings. Journal of Building Construction and Planning Research, 6, 112-121.

https://doi.org/10.4236/jbcpr.2018.63008

Received: June 6, 2018

Accepted: July 22, 2018

Published: July 25, 2018

Copyright $\odot 2018$ by authors and Scientific Research Publishing Inc. This work is licensed under the Creative Commons Attribution International License (CC BY 4.0).

http://creativecommons.org/licenses/by/4.0/

\begin{abstract}
In the construction industry, silicone is primarily used as sealant material to fill gaps and cracks providing water and air-tightness to vertical construction projects reducing energy usage bills and enhancing the integrity of construction materials. This paper reports the results of spectral analysis of commonly used building sealant materials used in residential and commercial buildings. A dozen commercially available silicone-based sealant materials composed of different ingredients representing three manufacturer brands are characterized using Raman and UV-VIS-NIR spectroscopic techniques. The characteristic vibrational fingerprints of the selected sealant materials are summarized, and the Raman and reflectance spectra of the samples are also presented. It is observed that most of the samples appear to have similar vibrational band assignments and reflectance spectra. However, analysis of the Raman spectral positions and the reflectance spectra reveals that there are distinct differences among the sealant materials.
\end{abstract}

\section{Keywords}

Silicone Sealant, Characterization of Construction Materials, Raman Spectra of Building Sealants, Reflectance Spectra of Silicone Sealants

\section{Introduction}

Silicone is a waterproof polymer extensively used to seal joints and voids to avoid water and air leakage through the building parts. It has been used for a wide range of applications including electronic devices, medical accessories, and in aerospace and construction industries [1], power systems [2], as coating material to improve electrical insulating property [3] [4], and as a sealing material 
in electrochemical devices such as fuel cells [5], and other industrial applications [6]. Due to its hydrophobic property, silicone rubber is also one of the ideal choices for coating materials exposed to wet environmental condition [4]. Despite its several applications, silicone rubber appears to degrade eventually. The possible causes of aging and degradation are due to chemical, physical and radiation attacks. Recently, Chang et al., studied the effects of humidity and temperature change on the degradation of silicone rubber sealant used in fuel cell technology and found out that silicone rubber sealing materials severely degrade above $100^{\circ} \mathrm{C}$ temperature making it unsuitable for membrane fuel cells operating above this temperature [5]. These drawbacks of the polymer draw the attention of material researchers to continuously find a way to improve the material property and overcome the aging and eventual degradation of silicone [7] [8] [9].

In the construction industry, silicones are mainly used as sealant material to fill gaps and cracks providing water and air-tight residential and commercial building envelopes, reducing energy usage bills, water leakage through the building envelope, and to ensure that no ponding occurs to avoid accumulation of bacteria [1]. Though the primary use of silicone sealants in buildings is not to provide smoke tightness, there are also reports indicating their uses to prevent the spread of smoke leakage to the adjacent building envelopes [10]. The scope of this study is limited to spectroscopic characterization of some of the commonly used silicone based sealant materials used in residential and commercial building construction projects. The spectral signatures of the samples are identified using Raman spectroscopy. The reflectance characteristics of the samples are also studied using UV-VIS-NIR spectroscopy.

The use of spectroscopic techniques for characterization and study of building materials have been widely reported. In our earlier work [11], we reported the application of Raman technique for non-destructive characterization of construction materials including sanded grout and fire-barrier sealants. Fernández-Carrasco et al., demonstrated the use of IR spectroscopy for characterization and spectral assignments of cementitious materials used in construction industry [12]. Due to the nondestructive nature of the technique, Raman spectroscopy is becoming an ideal tool for forensic analysis of the composition of construction materials and paintings used in ancient buildings [13] [14] [15]. Using IR spectroscopy, x-ray diffraction, and SEM Anderson et al., examined the sources, elemental and mineralogical compositions of the natural sediments used for wall plastering and foundations of five ancient buildings in Turkey [13]. The study suggested that soft lime and marlstone containing clay and silt were the materials used for wall finishing and construction of the foundations. Lampakis et al., used Raman spectroscopy to investigate the pigments and binder materials used in wall paintings of ancient churches and monasteries in Greece [14]. The study found that the paintings contain chalk, $\mathrm{Fe}_{2} \mathrm{O}_{3}$, charcoal, lead, mercury, and a toxic ore of mercury called cinnabar. On the other hand, Brough and Atkinson, used Raman spectroscopy to detect the presence of a silicate min- 
eral called thaumasite in concrete structures, and for forensic analysis and monitoring of its formation causing potential defects and deteriorations in concrete structures [15].

\section{Materials and Methods}

This study used commercially available twelve different silicone-based white sealant materials used in residential and commercial building construction for the analysis. A brief description of the three brands as provided by the manufacturers is summarized in Table 1. Depending on the type of the sealant and the ingredients, the materials selected are commonly used for filling joints, surface defects, plumbing, kitchen, sidings, bath, doors, and windows for indoor and outdoor uses. For instance, the ingredients listed for sample S1 by the manufacturer are calcium carbonate, ethylene glycol, titanium dioxide, and other additives, and meets ASTM C-834, standard specification for latex sealants [16]. Whereas, sample S2, with the same brand as S1, contains calcium carbonate, acrylic polymer mixture, diisononyl phthalate, propylene glycol, titanium dioxide, and other additives, and meets ASTM C-920, standard specification for elastomeric joint sealants [17]. The ingredients of sample S3 includes 50 - 75 percent by weight of limestone, Petroleum distillates, and Diethylene glycol dibenzoate each 1.0 - 2.5 percent, and Titanium dioxide, and Quartz, each 0.1 - 1.0 percent by weight [18]. The ingredients of sample S4 includes $50-75$ percent by weight of limestone, Dipropylene glycol dibenzoate, Petroleum distillates, and Diethylene glycol dibenzoate each 1.0 - 2.5 percent, and Titanium dioxide, Quartz, and Carbon black each 0.1 - 1.0 percent by weight [19].

The application of these techniques reported here in this paper has been widely used in the study of pharmaceutical products, mineralogical compositions, petroleum industry, forensic research, food sciences, semiconductor, and agro-industries. This study attempts to use Raman, FTIR and UV-VIS-NIR spectroscopic techniques to study silicone based sealant materials widely used in residential and commercial buildings and reports the spectral signatures of the selected samples. The primary purpose of this work is to report the vibrational signatures of commercially available silicone-based sealant materials used in construction industry. The Raman scattering measurements presented in Figures 1-4 and the characteristic spectral fingerprints of all the silicone sealants summarized in Table 2 are recorded using a compact Enwave Optronics Inc., Raman spectroscopy system equipped with $785 \mathrm{~nm}$ excitation wavelength laser and spectral coverage of $250-2350 \mathrm{~cm}^{-1}$. All the measurements were carried out with $100 \mathrm{~mW}$ laser power at the laser output port placed at an optimum distance of $7 \mathrm{~mm}$ from the sample. Further details of the Raman experimental setup and a schematic diagram of the system is presented in our earlier work [11]. The reflection measurements were carried out at 100 millisecond integration time and ten scan averaging using a broadband DH-2000 UV-VIS-NIR Halogen light source and a USB 2000 UV-VIS-ES spectrometer, with a usable band width 
Table 1. Description of the samples selected from three different manufacturer brands.

\begin{tabular}{cccc}
\hline Brands & Sample \# & *Description of the Samples & *Remark \\
\hline \multirow{2}{*}{ HDX } & S1 & Latex plus silicone caulk, SKU 156 943 & Meets ASTM C-834 \\
& S2 & Premium elastomeric plus silicone caulk, SKU & Meets ASTM C-920 \\
& S3 & Alex Fast dry acrylic latex caulk plus silicone & Exceeds ASTM C-834 \\
& S4 & Alex plus acrylic latex caulk plus silicone & Exceeds ASTM C-834 \\
${ }^{*}$ DAP & S5 & Silicone max, 100\% silicone & Meets ASTM C920 \\
& S6 & Kiwi seal ultra premium siliconized sealant & \\
& S7 & Kiwik seal plus & \\
& S8 & $100 \%$ silicone sealant, UV resistant & \\
& S9 & Silicone 2 ${ }^{+}, 100 \%$ silicone & Meets ASTM C-920 \\
& S10 & Silicone 1 ${ }^{+}, 100 \%$ silicone & Meets ASTM C-920 \\
& S11 & GE paintable and waterproof & Exceeds ASTM C-834 \\
\hline
\end{tabular}

${ }^{*}$ Based on the manufacturer, ${ }^{\mathrm{q}}$ Dicks-Armstrong-Pontius.

Table 2. Summary of selected silicone-based building sealant materials and the corresponding vibrational spectra.

\begin{tabular}{|c|c|c|c|c|c|c|c|c|c|c|c|c|}
\hline \multirow{2}{*}{$\begin{array}{l}\text { Raman spectrum } \\
\qquad\left(\mathrm{cm}^{-1}\right)\end{array}$} & \multicolumn{2}{|c|}{ HDX } & \multicolumn{5}{|c|}{ DAP } & \multicolumn{5}{|c|}{$\mathrm{GE}$} \\
\hline & $\mathrm{S} 1$ & $\mathrm{~S} 2$ & S3 & $\mathrm{S} 4$ & S5 & S6 & S7 & S8 & S9 & $\mathrm{S} 10$ & $\mathrm{~S} 11$ & $\mathrm{~S} 12$ \\
\hline 274 & $\mathrm{x}$ & $\mathrm{x}$ & $\mathrm{x}$ & $\mathrm{x}$ & & & $\mathrm{x}$ & & & & $\mathrm{x}$ & $\mathrm{x}$ \\
\hline 327 & & & & & & & & & & $\mathrm{x}$ & & \\
\hline 437 & & & $\mathrm{x}$ & $\mathrm{x}$ & & $\mathrm{x}$ & $\mathrm{x}$ & & & & $\mathrm{x}$ & $\mathrm{x}$ \\
\hline 481 & & & & & $\mathrm{x}$ & & & $\mathrm{x}$ & $\mathrm{x}$ & $\mathrm{x}$ & & \\
\hline 607 & & & $\mathrm{x}$ & $\mathrm{x}$ & $\mathrm{x}$ & $\mathrm{x}$ & $\mathrm{x}$ & & $\mathrm{x}$ & & $\mathrm{x}$ & \\
\hline 612 & & & & & & & & & & $\mathrm{x}$ & & $\mathrm{x}$ \\
\hline 704 & $\mathrm{x}$ & $\mathrm{x}$ & $\mathrm{x}$ & $\mathrm{x}$ & $x$ & & $\mathrm{x}$ & $\mathrm{x}$ & $\mathrm{x}$ & $\mathrm{x}$ & $\mathrm{x}$ & $\mathrm{x}$ \\
\hline 780 & & & & & $\mathrm{x}$ & & & $\mathrm{x}$ & $\mathrm{x}$ & $\mathrm{x}$ & & \\
\hline 802 & & & & & & $\mathrm{x}$ & & & & & & \\
\hline 851 & $\mathrm{x}$ & $\mathrm{x}$ & $\mathrm{x}$ & $\mathrm{x}$ & $\mathrm{x}$ & & $\mathrm{x}$ & $\mathrm{x}$ & $\mathrm{x}$ & $\mathrm{x}$ & & $\mathrm{x}$ \\
\hline 864 & & & & & & & & & & & $\mathrm{x}$ & \\
\hline 902 & & & & & & & & & & & $\mathrm{x}$ & \\
\hline 980 & & & & & & & & & & & $\mathrm{x}$ & \\
\hline 995 & & & $\mathrm{x}$ & $\mathrm{x}$ & & & $\mathrm{x}$ & & & & & $\mathrm{x}$ \\
\hline 1030 & $\mathrm{x}$ & $\mathrm{x}$ & & & & & & & & & & \\
\hline 1079 & $\mathrm{x}$ & $\mathrm{x}$ & $\mathrm{x}$ & $\mathrm{x}$ & & & $\mathrm{x}$ & & & & $\mathrm{x}$ & $\mathrm{x}$ \\
\hline 1245 & & & & & & & & & & & $\mathrm{x}$ & \\
\hline 1256 & & & & & $\mathrm{x}$ & & & $\mathrm{x}$ & $\mathrm{x}$ & $\mathrm{x}$ & & \\
\hline 1263 & $\mathrm{x}$ & $\mathrm{x}$ & & & & & & & & & & \\
\hline 1271 & & & & $\mathrm{x}$ & & & & & & & & \\
\hline 1294 & & $\mathrm{x}$ & & & & $\mathrm{x}$ & & & & $\mathrm{x}$ & $\mathrm{x}$ & \\
\hline 1307 & & & & & & & & & & $\mathrm{x}$ & & \\
\hline 1342 & & & & & & & & & & & $\mathrm{x}$ & \\
\hline 1386 & $\mathrm{x}$ & & & & & & $\mathrm{x}$ & & & & & \\
\hline
\end{tabular}




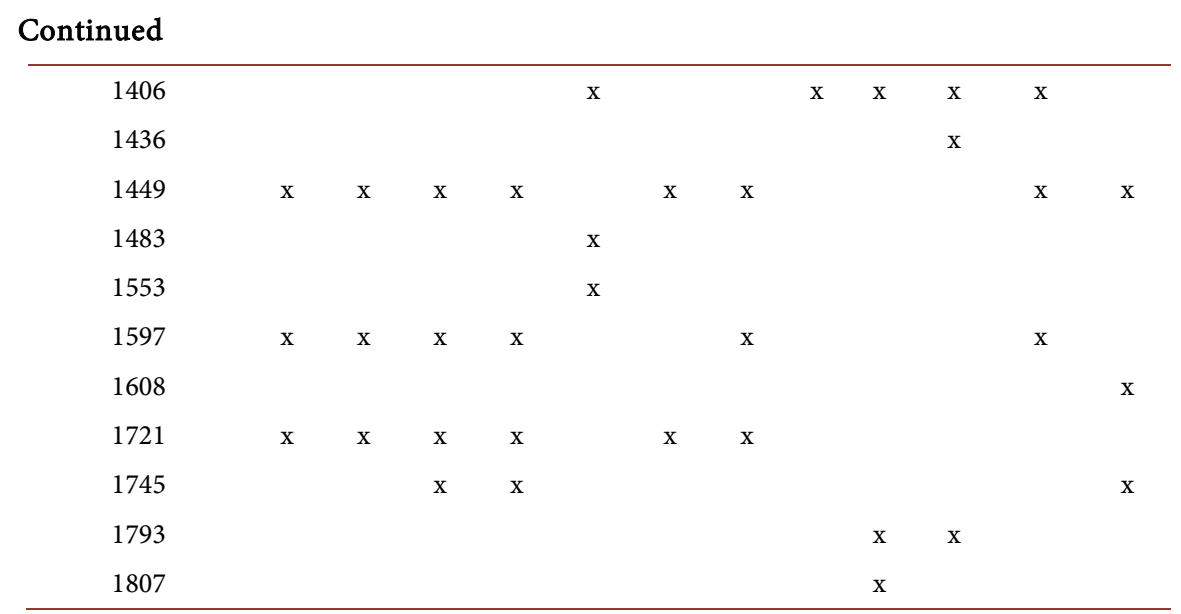

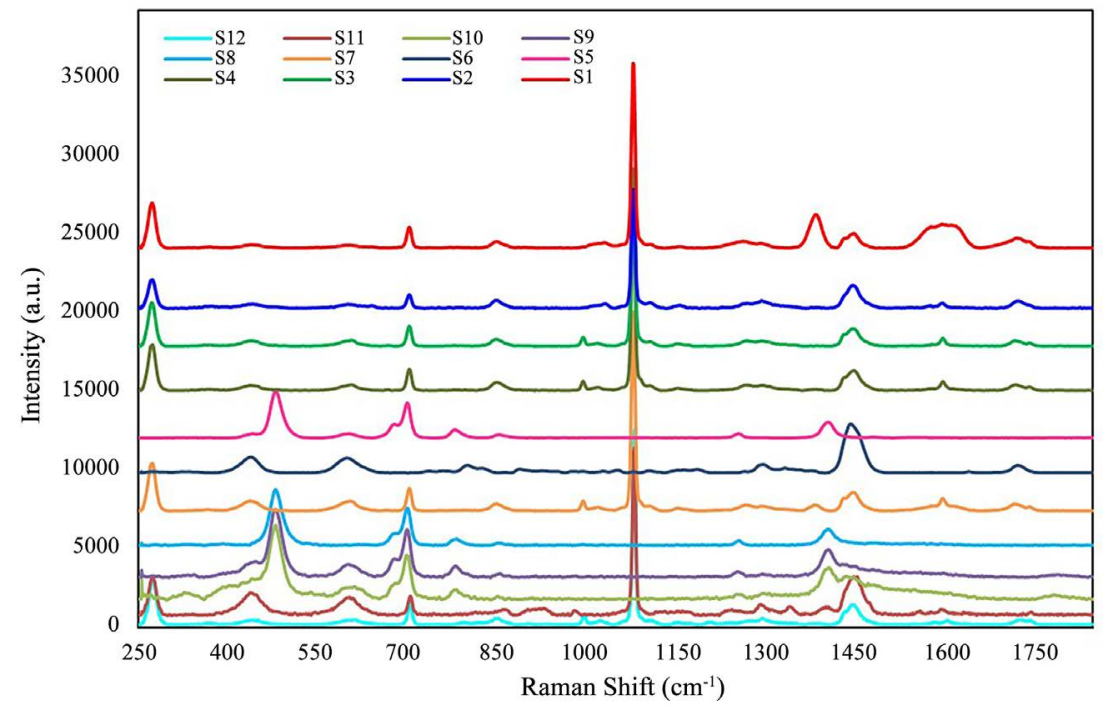

Figure 1. Raman spectra of all twelve samples measured with an integration time of 10 seconds and $100 \mathrm{~mW}$ power using $785 \mathrm{~nm}$ laser.

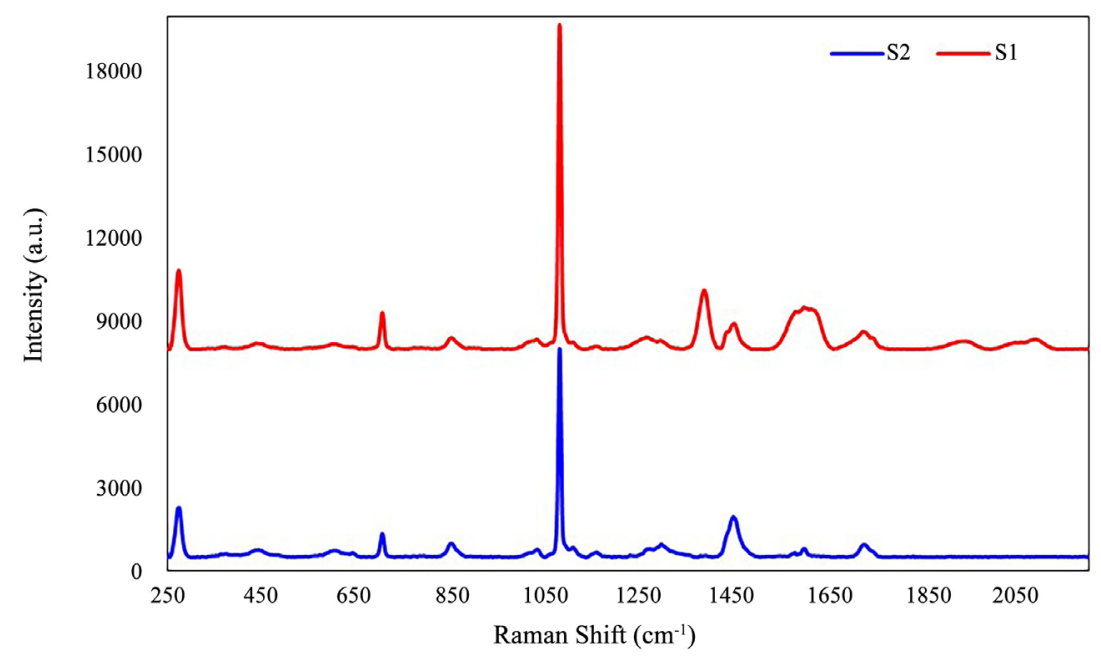

Figure 2. Raman spectra of sample S1 and S2 (HDX brand) measured with an integration time of 10 seconds and $100 \mathrm{~mW}$ power using $785 \mathrm{~nm}$ laser. 


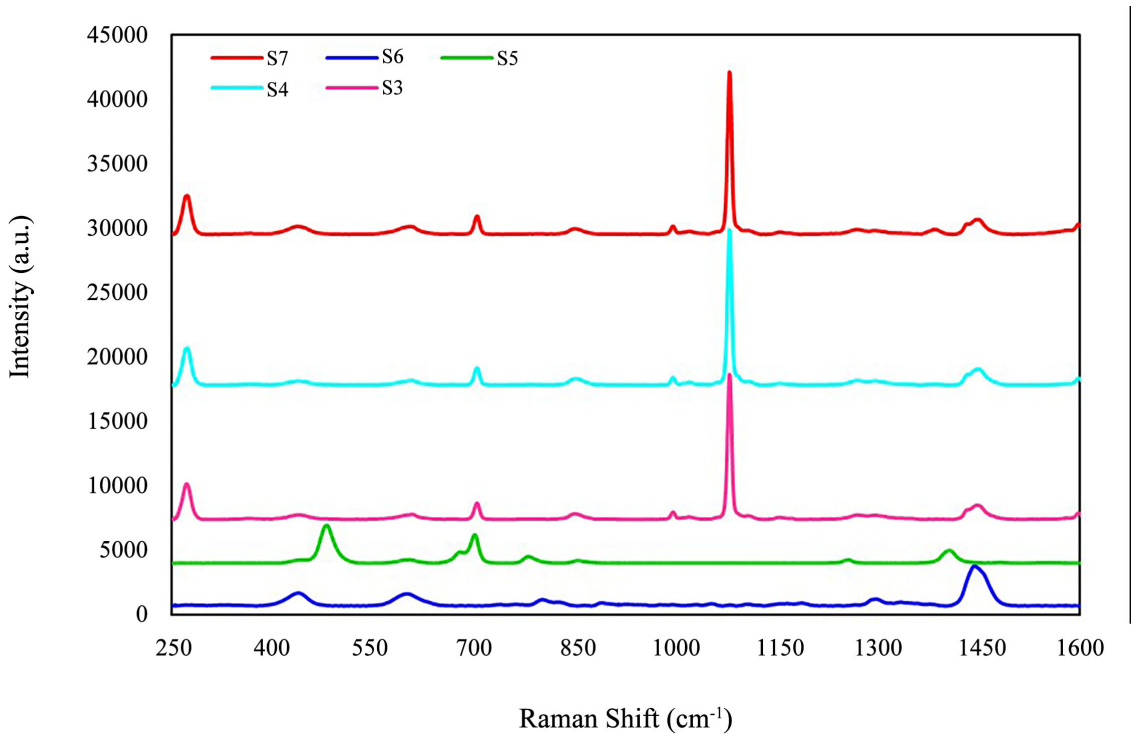

Figure 3. Raman spectra of sample S3-S7 (DAP brand) measured with an integration time of 10 seconds and $100 \mathrm{~mW}$ power using $785 \mathrm{~nm}$ laser.

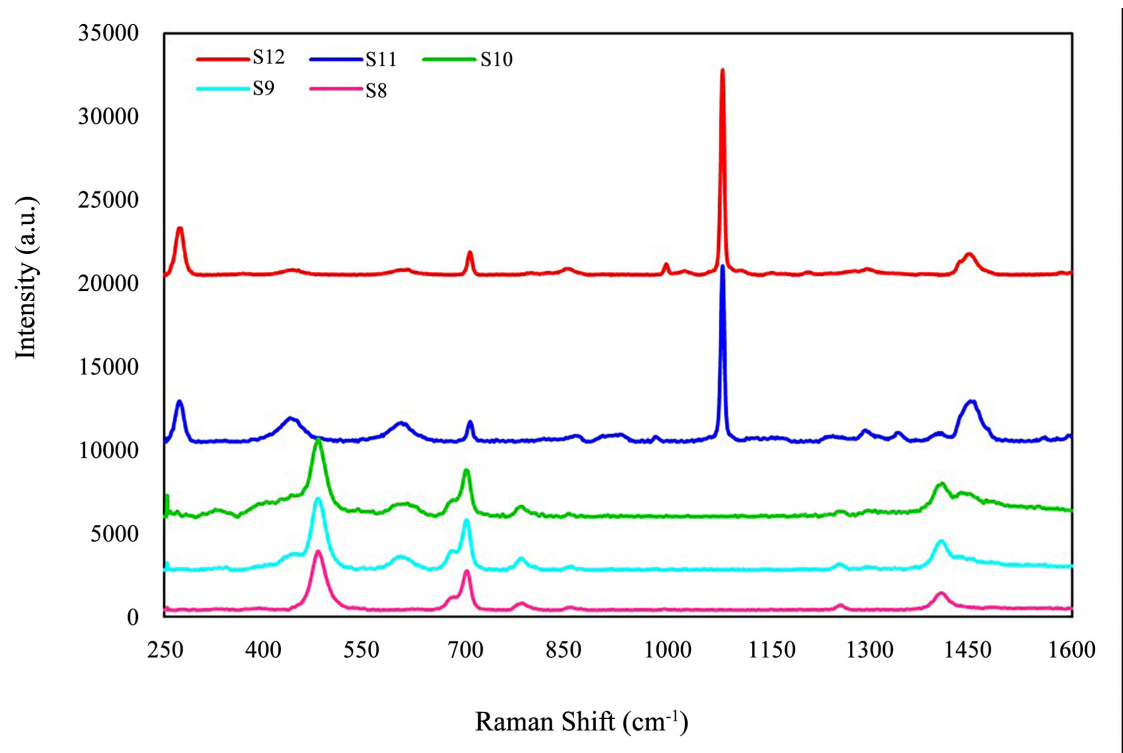

Figure 4. Raman spectra of sample S8-S12 (GE brand) measured with an integration time of 10 seconds and $100 \mathrm{~mW}$ power using $785 \mathrm{~nm}$ laser.

ranging from $200-850 \mathrm{~nm}$ interfaced with SpectraSuite software (Ocean Optics). For ease of comparison of the relative intensities and position of the characteristic Raman spectra of all the twelve samples studied, the results presented are all measured with $100 \mathrm{~mW}$ laser power at 10 seconds integration time.

\section{Results and Discussions}

Figure 1 shows the position and the relative intensities of the Raman bands of all the samples within $250-1800 \mathrm{~cm}^{-1}$ spectral range. A cursory look at the Raman and the reflectance spectra shown in Figure 1 and Figure 5, respectively, show 
that most of the samples appear to be identical with very minor differences in spectral assignments of the Raman bands and the reflectance spectra. However, a detailed analysis of the Raman spectral positions shown in Table 2 reveals that there are distinct differences among the sealant materials. Figure 2 shows the Raman spectra of the two HDX brand sealants studied (S1 and S2), which appeared to have eight similar (identical) characteristics Raman bands at $274 \mathrm{~cm}^{-1}$, $704 \mathrm{~cm}^{-1}, 851 \mathrm{~cm}^{-1}, 1030 \mathrm{~cm}^{-1}, 1079 \mathrm{~cm}^{-1}, 1263 \mathrm{~cm}^{-1}, 1449 \mathrm{~cm}^{-1}, 1597 \mathrm{~cm}^{-1}$ and $1721 \mathrm{~cm}^{-1}$. The only spectra differentiating two samples are the two Raman lines located at $1386 \mathrm{~cm}^{-1}$ and $1294 \mathrm{~cm}^{-1}$, which are unique to sample S1 and S2 respectively (Table 2). As can be seen in the figure, both S1 and S2 have one sharp and intense Raman band in the $1079 \mathrm{~cm}^{-1}$ region. Here, the bands at $1030 \mathrm{~cm}^{-1}$ and $1263 \mathrm{~cm}^{-1}$ do not appear within the samples selected from DAP and GE.

Figure 3 shows the Raman spectra of the five DAP brand silicone samples (S3-S7) measured with integration time of 10 seconds. Among the five samples S3, S4, and S7 also have ten Raman bands common to all the three samples in the $274 \mathrm{~cm}^{-1}, 437 \mathrm{~cm}^{-1}, 607 \mathrm{~cm}^{-1}, 704 \mathrm{~cm}^{-1}, 851 \mathrm{~cm}^{-1}, 995 \mathrm{~cm}^{-1}, 1079 \mathrm{~cm}^{-1}, 1449$ $\mathrm{cm}^{-1}, 1597 \mathrm{~cm}^{-1}$, and $1721 \mathrm{~cm}^{-1}$ region. In addition to the ten bands, what makes S4 and S7 different is the additional Raman band at $1271 \mathrm{~cm}^{-1}$ that S4 has, and a band at $1386 \mathrm{~cm}^{-1}$ region which is unique to S7. Sample S5 on the other hand, has nine Raman bands at $481 \mathrm{~cm}^{-1}, 607 \mathrm{~cm}^{-1}, 704 \mathrm{~cm}^{-1}, 780 \mathrm{~cm}^{-1}, 851 \mathrm{~cm}^{-1}, 1256$ $\mathrm{cm}^{-1}, 1406 \mathrm{~cm}^{-1}, 1483 \mathrm{~cm}^{-1}$ and $1553 \mathrm{~cm}^{-1}$. Among these, about half of the bands do not appear in the other DAP brand silicone sealants. Sample S6 has only six Raman spectra located at $437 \mathrm{~cm}^{-1}, 607 \mathrm{~cm}^{-1}, 802 \mathrm{~cm}^{-1}, 1294 \mathrm{~cm}^{-1}, 1449 \mathrm{~cm}^{-1}$, and $1721 \mathrm{~cm}^{-1}$. The bands at $802 \mathrm{~cm}^{-1}$ and $1294 \mathrm{~cm}^{-1}$ do not appear in the other four DAP samples. The bands located in the $802 \mathrm{~cm}^{-1}$ and $1271 \mathrm{~cm}^{-1}$ regions occurs only within the samples S6 and S4 respectively, and bands at $1483 \mathrm{~cm}^{-1}$ and $1553 \mathrm{~cm}^{-1}$ appear within sample $S 5$.

Characteristic Raman spectra of five GE brand silicone samples (S8-S12) are shown in Figure 4. As can be seen, samples S11 and S12; and S8, S9, and S10 appear to have similar spectral signatures. Both samples S11 and S12 display a very strong peak at $1079 \mathrm{~cm}^{-1}$ region. However, for samples S8, S9, and S10, the major bands are located at $480 \mathrm{~cm}^{-1}$ and $702 \mathrm{~cm}^{-1}$. The GE brand sample $S 8$ has Raman bands at $481 \mathrm{~cm}^{-1}, 704 \mathrm{~cm}^{-1}, 780 \mathrm{~cm}^{-1}, 851 \mathrm{~cm}^{-1}, 1256 \mathrm{~cm}^{-1}$, and 1406 $\mathrm{cm}^{-1}$. In addition to all the Raman spectra listed for sample S8 above, sample S9 has three Raman bands at $607 \mathrm{~cm}^{-1}, 1793 \mathrm{~cm}^{-1}$, and $1807 \mathrm{~cm}^{-1}$ region, which makes it different from sample 8. On the other hand, sample S10 can be differentiated from $S 8$ with the distinct spectra that $S 10$ has at $327 \mathrm{~cm}^{-1}, 612 \mathrm{~cm}^{-1}$, $1294 \mathrm{~cm}^{-1}, 1307 \mathrm{~cm}^{-1}, 1436 \mathrm{~cm}^{-1}$, and $1793 \mathrm{~cm}^{-1}$. Here it is worth pointing out that, the Raman bands at $327 \mathrm{~cm}^{-1}, 1307 \mathrm{~cm}^{-1}$, and $1436 \mathrm{~cm}^{-1}$ region appeared to be unique to GE brand S10 sample.

As can be seen in Figures 2-4, and Table 2, both HDX samples S1, S2; DAP samples S3, S4, S7; and GE brands S11 and S12, possess a very intense Raman line at $1079 \mathrm{~cm}^{-1}$ region indicating the presence of C-C stretching mode com- 
mon to seven of the twelve samples [20]. Samples S5 (DAP brand), and three GE brands S8, S9, and $S 10$ have a vibrational spectrum at $481 \mathrm{~cm}^{-1}$, indicating the presence of Si-O symmetric stretching bond in the samples [21]. Except for S6, all the other silicone sealant samples appear to have a vibrational band at 704 $\mathrm{cm}^{-1}$, which is assigned to C-Si-C symmetric stretching mode [21]. From the reflectance spectra illustrated in Figure 5 and Figure 6, we can see that all the samples except GE S8, all the silicone sealants studied appear to have a great deal of similarity in spectral range and relative intensities of the reflectance property of the materials.

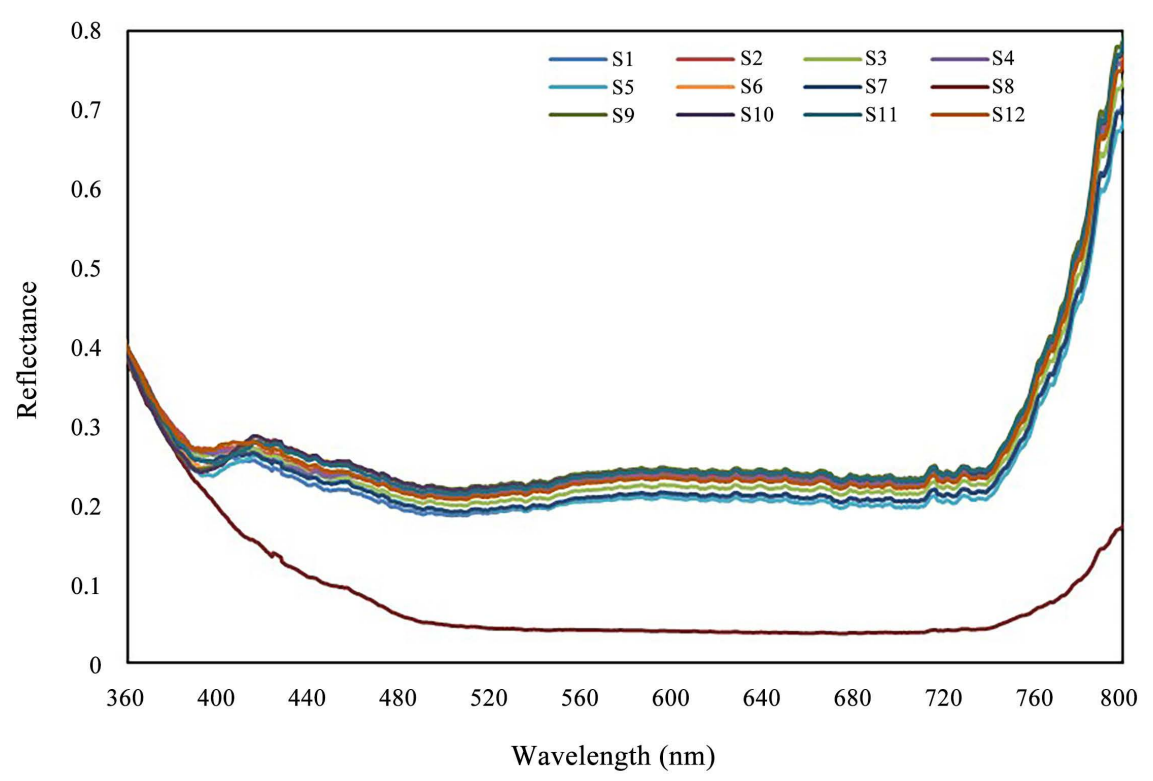

Figure 5. Reflectance spectra of samples S1-S12.

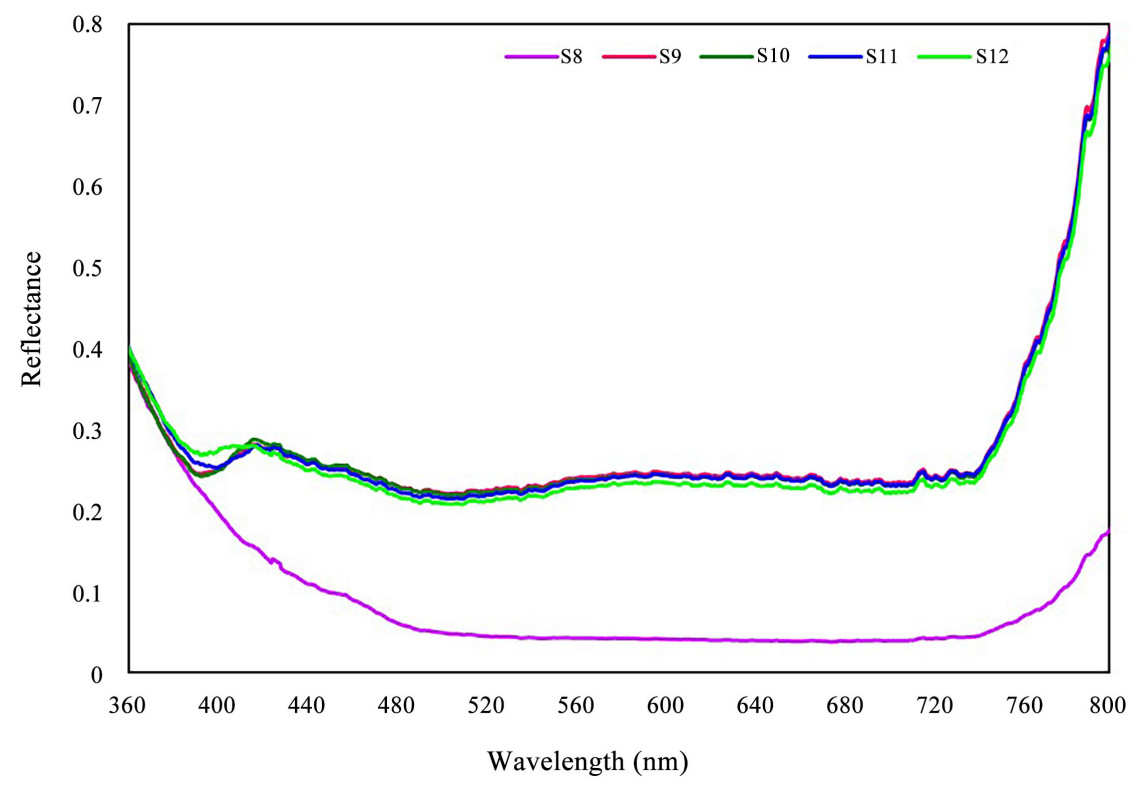

Figure 6. Reflectance spectra of GE samples S8 and S12. 


\section{Conclusion}

The suitability of the Raman and reflectance spectroscopy techniques for spectral analysis and characterization of building materials is successfully demonstrated using commercially available silicone sealant materials used in residential and commercial building construction projects. Twelve different samples were selected from three different manufacturer brands. It is found that there are several vibrational bands which are common to some of the samples, suggesting that there is a reasonable similarity in molecular composition of the samples drawn from different manufacturer brands. As shown in Table 2 and Figures 1-4, despite the multiple similarities in the spectral bands of the sealant materials studied, Raman spectroscopic technique provided enough evidence to distinguish the samples and suggest that the molecular structure of most of the silicone brands are not identical. The system is reliable, portable, relatively inexpensive and needs minimal to none sample preparation, and rapid measurement time which makes it an ideal tool for analysis of building materials in a laboratory setting. The drawback of this system for outdoor in-situ characterization of materials on construction site is the negative impact of ambient light, which interferes with measurements resulting in contamination of Raman spectra from the ambient light, and the effects it will have on the signal-to-noise ratio of the spectra.

\section{Acknowledgements}

This work is supported by the Department of Homeland Security-Scientific Leadership Award, under Grant Nos. DHS-SLA 2014-ST-062-000060, and 2014-ST-062-00060-02.

\section{References}

[1] Silicone, American Chemistry Council, Inc. (2014). https://www.chemicalsafetyfacts.org/silicones-post/

[2] Wen, X., Yuan, X., Lan, L., Hao, L., Wang, Y., Li, S., Lu, H. and Bao, Z. (2017) RTV Silicone Rubber Degradation Induced by Temperature Cycling. Energies, 10, 1-12. https://doi.org/10.3390/en10071054

[3] Jia, Z., Fang, S., Gao, H., Guan, Z., Wang, L. and Xu, Z. (2008) Development of RTV Silicone Coatings in China: Overview and Bibliography. IEEE Electrical Insulation Magazine, 24, 28-41. https://doi.org/10.1109/MEI.2008.4473052

[4] Kim, S.H., Cherney, E.A. and Hackam, R. (1992) Hydrophobic Behavior of Insulators Coated with RTV Silicone Rubber. IEEE Electrical Insulation Magazine, 27, 610-622. https://doi.org/10.1109/14.142726

[5] Chang, H., Wan, Z., Chen, X., Wan, J., Luo, L., Zhang, H., Shu, S. and Tu, Z. (2016) Temperature and Humidity Effect on Aging of Silicone Rubbers as Sealing Materials for Proton Exchange Membrane Fuel Cell Applications. Applied Thermal Engineering, 104, 472-478. https://doi.org/10.1016/j.applthermaleng.2016.05.095

[6] Polysiloxanes (Silicones), Polymer Properties Database (2015) http://polymerdatabase.com/polymer\%20classes/Silicone\%20type.html 
[7] Wu, J., Dong, J., Wang, Y. and Gond, B.K. (2017) Thermal Oxidation Aging Effects on Silicone Rubber Sealing Performance. Polymer Degradation and Stability, 135, 43-53. https://doi.org/10.1016/j.polymdegradstab.2016.11.017

[8] Feng, J., Zhang, Q., Tu, Z., Tu, W., Wan, Z., Pan, M. and Zhang, H. (2014) Degradation of Silicone Rubbers with Different Hardness in Various Aqueous Solutions. Polymer Degradation and Stability, 109, 122-128. https://doi.org/10.1016/j.polymdegradstab.2014.07.011

[9] Beigbeder, A., Linares, M., Devalckenaere, M., Degée, P., Claes, M., Beljonne, D., Lazzaroni, R. and Dubois, P. (2008) CH- $\pi$ Interactions as the Driving Force for Silicone-Based Nanocomposites with Exceptional Properties. Advanced Materials, 20, 1003-1007. https://doi.org/10.1002/adma.200701497

[10] Boström, L. (2002) Ageing Effects on the Fire Resistance of Building Structures. Brandforsk Project 322-011. SP Report 2002:29, SP Swedish National Testing and Research Institute, Borås.

[11] Kassu, A., Walker, L., Sanders, R., Farley, C., Mills, J. and Sharma, A. (2017) Nondestructive Spectroscopic Characterization of Building Materials. SPIE Smart Structures and Materials and Nondestructive Evaluation and Health Monitoring, Portland, Vol. 10169, 101692V-1.

[12] Fernández-Carrasco, L., Torrens-Martín, D., Morales, L.M. and Martínez-Ramírez, S. (2012) Infrared Spectroscopy in the Analysis of Building and Construction Materials, Infrared Spectroscopy. InTech, London. http://www.intechopen.com/

[13] Anderson, E., Almond, M.J. and Matthews, W. (2014) Analysis of Wall Plasters and Natural Sediments from the Neolithic Town of Çatalhöyük (Turkey) by a Range of Analytical Techniques. Spectrochimica Acta Part A: Molecular and Biomolecular Spectroscopy, 133, 326-334. https://doi.org/10.1016/j.saa.2014.04.072

[14] Lampakis, D., Karapanagiotis, I. and Katsibiri, O. (2017) Spectroscopic Investigation Leading to the Documentation of Three Post-Byzantine Wall Paintings. Applied Spectroscopy, 71, 129-140. https://doi.org/10.1177/0003702816654151

[15] Brough, A.R. and Atkinson, A. (2001) Micro-Raman Spectroscopy of Thaumasite. Cement and Concrete Research, 31, 421-424. https://doi.org/10.1016/S0008-8846(00)00459-2

[16] ASTM C 834-00 (2000) Standard Specification for Latex Sealants.

[17] ASTM C 920-98 (1998) Standard Specification for Elastomeric Joint Sealants.

[18] DAP (2015) Safety Data Sheet. SDS No. 00010013001.

[19] DAP (2016) Safety Data Sheet. SDS No. 00010002001.

[20] Cai, D., Neyer, A., Kuckuk, R. and Heise, H.M. (2010) Raman, Mid-Infrared, Near-Infrared and Ultraviolet-Visible Spectroscopy of PDMS Silicone Rubber for Characterization of Polymer Optical Waveguide Materials. Journal of Molecular Structure, 976, 274-281. https://doi.org/10.1016/j.molstruc.2010.03.054

[21] Jayes, L., Hard, A.P., Séné, C., Parker, S.F. and Jayasooriya, U.A. (2003) Vibrational Spectroscopic Analysis of Silicones: A Fourier Transform-Raman and Inelastic Neutron Scattering Investigation. Analytical Chemistry, 75, 742-746. https://doi.org/10.1021/ac026012f 